\title{
Play and Festival: The Role of Participation in the Experience of Art
}

\author{
Abdollah Amini \\ Ph.D. Candidate in Philosophy, \\ University of Isfahan, Iran \\ E-mail: aminiphilosophy@gmail.com
}

Mohammad Javad Safian

Assistance professor of philosophy University of Isfahan

\section{Doi:10.5901/mjss.2013.v4n3p769}

\begin{abstract}
In order to avoid subjectivism hidden in the basis of modern aesthetics -established by Kant- Gadamer (1900-2002) proposes the experience of art in the form of play, which is consistent with other hermeneutical components of his thought. A work of art as play is no longer a mere object of "aesthetic consciousness", but it is a totality in which we take part. A live and full presence in the paly of art is both theoretical and practical experience. This kind of participation in the paly of a work of art can be sought in other cases which are a kind of play themselves, i.e. festivals, celebrations and religious rites. However, it seems that the concept of participation regarding the paly of art has two modes: one is that the participation means to accompany other people in a presentation and have a collective experience and the other means to attend in play of a work of art without paying attention to the presence of other people. It seems that Gadamer has been swaying from one participation dimension to another.
\end{abstract}

Key words: aesthetic consciousness, work of art, experience of art, festival, participation, play

\section{Introduction}

Proposing the concept of participation and its centrality in the form of the concepts of play (spie/) ${ }^{1}$ and festival as a kind of presentation in the domain of the experience of art and works of arts, Gadamer does not mean to establish aesthetics as an independent branch of philosophy in its modern sense, but he pursues a more widespread end. His aim, in general is to explain "the event of understanding" and its conditions. Truth occurs in this domain and its understanding is possible in a particular mode as well. Hence, proposing the experience of art and questioning of the truth of art are only one part Gadamer's attempt placed under his more general proposal-hermeneutics as the science of interpretation. It is with such an attitude that he speaks of the aesthetic "integration" in hermeneutics (Gadamer, 2004, p. 157). Since works of art are considered as "texts" in which the meaning and truth lie, they are objects of understanding and thus are included in hermeneutics. Gadamer in the article "aesthetics and hermeneutics" (1964) tries to show such a relation. Regarding such a relation between hermeneutics and aesthetics in Gadamer's constellation of thought, it is natural that many of his central hermeneutic components are involved in the experience of art.

In order to criticize the domination of methodology of natural sciences over human sciences, Gadamer paid attention to the realm of Kantian aesthetics to show that the mode of manifestation and openness of the truth in this domain (as one of the acute examples of human sciences) is not merely limited in the tight form of method; therefore, he attempts to confirm it for the total domain of human sciences. With such an attitude, he criticized that concept which he called "aesthetic consciousness". His alternative for the deliverance of such an abstraction and differentiation as the results of subjectivist mode lying in the modern aesthetic foundation, is proposed in the form of the central concept of

1 . Regarding the differences and similarities of play and game both implied in spiel, see: (Vikhagen, 2009). To criticize Gadamer's view on the issue that he does not consider any differentiation between art and sport and he does not provide sufficient reason in referring art to sport, see: (Graham, 2004, pp 41-44). 
"play" (and also some other concepts such as festival, symbol, allegory, imitation, image, ect.) which is the very nature of understanding as play as well. Proposing the concept of play in Gadamer's constellation of thought is considered as "the clue to ontological explanation" (Gadamer, 2004, p. 102), in such a way that it can be claimed that proposing this concept regarding the experience of art is itself the issue which Gadamer calls as the "aesthetic non-differentiation". Gadamer refers to the case of festivals and religious rites to focus on the participation mode and involvement associated with it which are presentation themselves. Here, our discussion is focused upon the latter mode.

Gadamer first in Truth and Method (1960) established the general framework of these discussions (the experience of art in the form of the concept of play and some other concepts) and thereafter, in some of his other writings and articles, he pursued them with different focuses. In the article "The Play of Art" (1973), he pays attention to the importance and status of play in the human's whole cultural and social life and consequently the domain of art. In the article "The Relevance of the Beautiful: Art as Play, Symbol and Festival" (1986), he particularly focuses on the investigation of the concepts of play, symbol, and festival and their relation to art. And finally in the article "The Artwork in Word and Picture: 'So True, So Full of Being!" (1993), also he somehow addresses the results and importance of this mode of considering art and art experience. Relying on these works, we try to show the importance of the "participation" as an essential basis of the gadamer's transendence from "aesthetic consciousness" towards "hermeneutic consciousness". First of all, the proposition of Gadamer's perception of play and its various dimensions is perused and then, it is compared with the centrality of the aspect of participation in festival; then the discussion is concluded. ${ }^{2}$

\section{The concept of play and its various dimensions}

The concepts of play and festival, concerning their being presented, are not two parallel issues, but it can be said that the festival, the religious rites, celebrations and carnivals themselves are different kinds of play/presentation. Hence, the concept of play in Gadamer's constellation of thought enjoys a more important status. Therefore, considering the main components of play (here, the play of art is considered more), the implication of the concept of festival will become clearer. Gadamer, in the first part of Truth and Method, discusses the concept of play and its components appropriately and indicates its hermeneutic implications for the domain of art and art experience. In the article "The Relevance of the Beautiful" (pp. 22-31) he repeats the same components with different deletions or descriptionsin detail. Discussing the concept of play, Gadamer avoids defining it inclusively and exclusively, but in a phenomenological manner, each time, he discusses one of its component or dimension and looks at play from this perspective; therefore, he starts with a brief and common understanding and then achieves a detailed understanding of it.

Here,contrary to common thought, play merely has no aspect of entertainment and fun which we take refuge in to flee from the seriousness and impasses of everyday life. From this view, to Gadamer, play is "the status and flow of the life itself" (the play of art, 1973, p. 124), here, the concept of play is identical to the "language games" of Wittgenstein which are themselves like "forms of life". ${ }^{3}$ And also it should be added that play is our existential mode, hence the basis of all human activities related to the entirety of human culture. It is from this viewpoint that Gadamer speaks of the "basic role" of play in all our culture and everyday life (Gadamer, 1986, p. 22). ${ }^{4}$

Although play is not serious to the player regarding its being play, which is a criterion to define its border with serious affairs normally, there lies a "sacred" seriousness in this seemingly lack of seriousness. This criterion is just determinable outside of play because the play is not a promiscuous and arbitrary affair in its own right as a whole. But each play has its own laws, limitations and borderlines. In Wittgenstein's words, every work of art as play is itself a type of "language game" over which dominates a particular pattern. To take part in this play requires accepting and admitting such laws. Entering running play without obeying its rules and laws or ridiculing them mean the destruction of play and this means the violation of play rules and lack of participation in it. If we look from the perspective of the individual's own activities, outside play, he has the freedom to question its laws and rules and even he can reject them and does not take part in play, but as soon as he enters play and accept to take part in it, he must obey the laws of play and accept its terms. Hereupon, by participating in play one is projected into a totality where does not play the role of the determining

\footnotetext{
2. Here, to avoid prolonging the discussion, investigating the relationship of these concepts with other concepts including symbol, allegory, sign and etc. is avoided.

3 . For more information regarding the difference between Gadamer's consideration of play and Wittgenstein's approach of it, see: (Nordenstan, 1984, pp. 23-28).

4. Interpreting the central and canonical role of play and generalizing it to the whole cultural and social human life, Gadamer gets closer to a Heraclitian-Nietzschean interpretation.
} 
subject any longer, but as if he gets into play by play itself (Gadamer, 2004, pp 102-4). However, it does not mean the elimination of each kind of "anthropological" criterion in the experience of art because at least there is a kind of human perspective which playes an undeniable part in this experience. In fact this human perspective is not identical to the Cartesian subjectivism which, according to Gadamer, has penetrated to the modern aesthetics. But on the contrary, it is a kind of openness to a work of art before one has imposed his subjectivity upon it; however, it is undeniable that participation is itself a kind of interpretation which is not indeed unilateral. Gadamer in the article "The Relevance of the Beautiful" is to show us the anthropological foundation of our experience of arts (p 22). ${ }^{5}$

According to the latter discussion, another dimension of play which appears is that play always is presented for somebody. A piece of music or a film is always composed or made for a person as an audience; even nobody listens or watches them. A presentation is always the presentation of "something" for "someone". This mode of play's being focused spontaneously enters the audience as a participant into play. In this line, participation is one central component of play (or the festival). But, what does the concept of participation itself contain? What are more considered in the concept of participation are those aspects of vitality, mobility and movement which are necessary for it. Participation in this sense does not mean "aesthetic contemplation" (Schopenhauer) or speculative and tranquil one which drown in the subject of reflection and reach lack of wanting and lack of will, but participation means " being there present" alongside with an theoretically and practically active presence. We are not Cartesian subjects without time and space who participates in play of a work of art by the criteria of "clarity" and "distinction" and suspension of all other things including our body, rather we take part in play by prejudices, temporality and our particular conditions. In this respect, to Gadamer, play nor refers to the initial state of the mind of the creator of the work (artist) neither reduces to the audience's mere perception and feeling, but play or presentation is nothing but "the mode of being of the work of art" (Gadamer, 2004, 115). The concept of play in this sense transcends the Cartesian subject-object model. One participates in the play of a work of art but not as subjects which take the work of art as their objects. Performing play and presenting it is not something like the object and the individual who participates in its performing is not the subject (Weinsheimer, 1381, $p$. 33). Therefore, play to Gadamer is different from its subjective signification to Kant (as "harmony of cognitive faculties") and to Schiller (as "impulse of play"). Play, independent of our mind (as players and audiences), is "there". Therefore, should it be concluded that participating in play and accepting its laws is a totally passive issue; we play no role in the process of play and the way of its performing? Are we merely dependent on its laws? The answer is no; because in these conditions, the individual is more an actor rather than a mere observer. Although at first sight, concerning this issue that we are not the determining subjects of and the rules governing on play, regarding the components of Gadamer's hermeneutic approach we are somehow involved in the process of play and the way of its performing. Participating in the play of a work of art is not totally neutral and innocent, but each of us participates in the paly from the window of our attitudes and prejudices and from the heart of a specific historical tradition. In other words, the player also has his own horizon which fuses with the horizon of the text (play) and this action causes a kind of "dialogue" between the interpreter and the text to be occurred. Though the text enjoys_ particular potentialities, the interpreter approaches the text with his

\footnotetext{
5. Gadamer's criticism of modern aesthetics and his alternative in the form of the concept of play has agitated the reaction of some of supporters and opponents: Nordenstome does not consider Gadamer's approach regarding art and the experience of art much far from that of Kant (Nordenstome, 1984, p. 26). While considering some of the criticism of Gadamer on modern aesthetics as central, Kelly, contrary to him, believes that alienation aesthetic consciousness is not the result of subjective aesthetics, but is the effect of an erroneous interpretation of subjectivity. In his opinion, Gadamer's attention to the cognitive role of art in the form of self-understanding is more subjective (Kelly, 2004, 110-5). Although Scheibler speaks about this issue equivocally, he like Kelly believes that Gadamer's emphasis on the audience's self-understanding encountering a work of art is keeps the "pole ofsubjectivity" (Scheibler, 2001, pp. 163). Oskar Becker does not agree with distinction between aesthetic and historical-hermeneutical attitude of Gadamer's hermeneutics and does not accept this hermeneutic rule according to which the meaning of a work of art is dependent on its "historically effected consciousness" (as cited in Couzens Hoy, 1992, p. 235). But, in contrst to this view, Couzens Hoy knows the purpose of Gadamer's philosophical hermeneutics as transforming "Fundamental concepts of aesthetics" and calls Gadamer's view of classical aesthetics as a kind of "Hermeneutical poetics" (ibid. pp. 68, 184). Paying attention to "many results" of Gadamer's interpretation of the criticism of modern aesthetics, Palmer defends the advantage of his view and considers it as a basis for supporting his hermeneutics (Palmer, 2008, p. 193). Karnezis believes that if one views Gadamer's position as subjective one, it is a "great injustice" (Karnezis, 1987). Also in Ford's view, by applying the concept of play, Gadamer is to show our hermeneutical situation in the world to pass Dilthey's Cartesianism in this way and knows Gadamer's dialogical method as a response to dichotomy of subject-object. (Ford, 2006, p. 52). But it may be that some authors' reliance on the role of encountering a work of art and the experience of art in Gadamer's view, which results in selfunderstanding, and knowing Gadamer's interpretation as subjective are due to this negligence that they want to eliminate totally the subject or any kind of human perspective from all domains, especially that of art; while such an issue is principally impossible; because as long as human exists and think, both thinking and understanding is necessarily human.
} 
particular potentialities as well. It is considering such an issue that Gadamer claims that every play enjoys its own "spirit" (Gadamer, 2004, p. 107) and this issue is the basis of distinction of plays from each other.

However, from this point of view, the work of art is not considered as a static object which stands in relation to "aesthetic consciousness", but in every encountering, it becomes a "living experience" which involve us with itself and influences us: "Instead the work of art has its true being in the fact that it becomes an experience that changes the person who experiences it" (ibid, p. 103) .

The results of this view towards a work of art are a living play which is always "going on" and hence it is considered as an "unfinished event" which will never achieve the final meaning. The work of art is the play that is always repeatable for every individual. Polysemy or polyphony and also a kind of relativity (according to some critics such as Betti and Hirsch) which have shed light on the whole of Gadamer's hermeneutics, is true in this case. Therefore, another component of play is its medial sense; i.e. play is always performed within a tempo-spatial situation, hence an unfinished event. The paly of a work of art is confined to these conditions and contexts and has no sense outside them. The consequence of such a view is that the work of art, once and for all, has not been created by a genius artist, while our task is to eliminate the historical distance and achieve the same primary intention of the original author, but every encountering in relation with the work of art is itself tantamount to re-creation encouraged by the audience whose task is itself a unique event. Thus, it is better to say that every encountering with a work of art is more understood as a "recreation" than a "work" (Gadamer, 1973, p. 126). ${ }^{6}$ It means a creative and living process rather than a work which is a static and inactive matter. What is important in this issue and enjoys a canonical status is nor the mere artist's "intention" neither the mere audience feeling, but the individual's existential participation within play which is, independent of them, "there" and the consistency of the work is dependent on it. The works of art is present to us only where they are read and confronted, not where they are for example in library shelves and museums.

What does guarantee the consistency of play and construct its real nature? The answer is what we have previously discussed implicitly about the nature of participation and that is the important component of "movement" which is somehow implicated in the German word spiel. Hence, these concepts are intertwined internally. In fact, Gadamer, in his article "The Artwork in Word and Picture", by referring to the Aristotelian concept of energeia in his discussion of works of art and their mode of existence as living play, is going to induce this concept that the work of art is not a finished, static, created and once-and-for-all "work", but refers to a performing action which simultaneously guarantees both being and becoming, the energeia and ergon (Gadamer, 1993, pp. 209-10). ${ }^{7}$ Moving to-and-fro within play is not necessarily in line with an aim outside play which has been predetermined by its players or even does not refer to the final aim of the play itself which play has been constructed for its sake beforehand. The aim of play is within itself and is not such as a tool in line with an aim beyond itself and in Kant's words, play is a "purposiveness without a purpose", but all things are within these movement and participation. It is at the time of encountering when the aim is determined and the meaning is appeared in an interaction between the text and the interpreter. Therefore, the participation is another word for the dialogue between the text and the interpreter or "the fusion of the horizon" of the text and that of the interpreter. It is the element of movement that has the canonical importance and the question that this movement is in line with what aim, is unrelated regarding the domain of the paly of art. It is not unduly that Gadamer speaks of the "occurrence of movement"(2004, p. 104), it means that this concept is not predetermined and planned as the scientific method which he achieves a clear and calculable result by its applying and observing. This movement which somehow reinforce the nature of play is close to the considerations which Aristotle had of a live being as a self-movement issue whose movement resources are within it and these resources are not derived issues in such a way that they are imposed on the live being from its outside (Gadamer, 1986, p. 23). ${ }^{8}$

\footnotetext{
6 . In truth and method, regarding "recognition" Gadamer discusses that recognition is not recognizing something again which one recognizes a priori ("recollection" in Plato's word), but it is something more than it (Gadamer, 2004, p. 113).
}

\footnotetext{
7. Also see (Gadamer, 2004, p. 110) in which Gadamer speaks of two dimensions of energeia and ergon. Play enjoys ergon because it is always going on. However, a kind of potentiality and energeia lies in it since it contains locution for every individual as well as is exposable and repeatable for everyone. For this reason, Gadamer refers to this issue as "transformation into structure" which has these two dimensions in itself: "thus transformation into structure means that what existed previously exists no longer. But also that now exists, what represents itself in play of art, is lasting and true" (p. 111). Only by participating in play of a work of art, it transformes into a "structure", which itself is not more than play.

8. Gadamer's consideration of the mode of the existence of play as "self-presentation" is somehow close to this Aristotelian consideration.
} 
Another aspect of play is that it is a "whole" per se. It means that play is considered as an independent and dynamic event which enjoys its own nature, precedes the player's and the audience's consciousness and has "absolute independence" of them. Play is a whole which fascinates both the player and the audience to the same extent. Adopting this type of attitude to play, one can recognize the reflection of Nietzschean ideal and his interest to Greek tragedywhereboth the player and the audience were involved at the same time- in his the Births of Tragedy (1870).

On the other hand, play is a process which occurs in-between the player and the audience. Although the play per se has its own rules independent of these two, one cannot deny that play is performed "by" someone and "for" someone else. The place between the player and the audience is not so rigid and firm that one is totally active and the other is completely passive, but in the process of participation, the audience takes the place of the player, hence the difference of these two is ruled out (Gadamer, 2004, p.110). Now, the play can be defined in such a way that it includes some mentioned components: play is that independent, systematic, serious and dynamic whole going on and having an internal end which both the player and the audience are participating simultaneously.

\section{Participation as the common component between play and festival}

What make the concepts of play and festival close to each other are on the one hand, the mode of the lack of separation of their performing from the presentation itself and on the other hand, the mode of participation as their central component. Performing play or festival is identical to them, not something more than or beside them. A festival or play achieves their true nature only in the process of performing. The presence or existence of a festival only depends on its holding and celebrating. Without this, the existence of a festival would be limited to some of its memorials in the individual's historical mentality. However, the consistency and existence of a festival, like those of play, are not completely dependent on and limited to the mentality of those who are the moderators of its holding, "rather, the festival is celebrated because it is there" (Gadamer, 2004, p. 121). To Gadamer, this "being there" means "to participate". Participation has the "intersubjective" aspect. A festival is a collective experience where individuals unite."A festival is an experience of community and represents community in its most perfect form. A festival is meant for everyone" (Gadamer, 1986, p. 39).

To hold a festival requires congregation and participation in a temporal and collective experience and to abandon any everyday job or activity which results in dispersion of individuals. "The celebration of a festival is, in technical terms, an intentional activity. We celebrate inasmuch as we are gathered for something, and this is particularly clear in the case of the experience of art. It is not simply the fact that we are all in the same place, but rather the intention that unites us and prevents us as individuals from falling into private conversations and private, subjective experiences" (Gadamer, 1986, p. 40). The modes of participation and involvement in a festival create a kind of belonging and the individual finds himself as part of the process of celebration as a whole. For example, in performing a religious rite, the individual who has a role in its holding, he knows himself to belong to it and feel happy because he has found the opportunity to participate in it and to enjoy its spiritual blessings. When he speaks of the way of its performing, he knows it as a universal and collective experience and talks about its performing by plural expressions. Gadamer also speaks of the "festival of art" because the works of art especially the performing arts have festival characteristics. Therefore, there are commonalities between the festival as a collective experience and the play of art which some of them are as follows: 1 . The central element of participation involving in both of them, 2. The temporal structure (which is itself a unique issue while every presentation or performance would is repeatable), 3 . The central role of the performing mode in both as one of enforcing components of them, and 4. A kind of "purposiveness without a purpose" governing them.

In case festival, the mode of performing -which itself necessitates participation- is temporal and every performance has its own particular temporality. From this viewpoint, holding festivals periodically is neither mere "repetition" of previous periods and performances nor something basically alien and totally unrelated to them, but it is a kind of new experience which has its own nature that presents the notion of time particularly. Works of art are also temporal and our encountering with them is a temporal and historical issue. They are contemporaneous for every period and age. Accordingly, Gadamer claims that ancient works of art have a "living presence" for us (Gadamer, 1993, p. 198). But, neither is it possible that one brings the ancient works and texts to the present time, nor the present time abandons totally its status quo and projects itself into the ancient time of works of art. For this reason, Gadamer speaks of a dialectic relationship between temporality and timelessness of a work of art. On the one hand, a work of art is timeless because it is not limited to a particular period of time, but on the other hand, it is temporal since in any time and any encountering, one can approach it and interpret it (Khatami, 1387, p. 140). The work of art, in Gadamer's word, is located in a "timeless present"(Gadamer, 1986, p. 96). Although a work of art, with respect to its creation, has been created by an artist in 
aspecified period of time, this issue does not prevent that one cannot come into dialogue with it in the next periods of time. The work of the past has a talk with us and says "something" to us.

"Works of art possess an elevated rank in being, and this is seen in the fact that in encountering a work of art we have the experience of something emerging —and this one can call truth" (Gadamer, 1993, p. 207). This presentation of the artwork of the past which still can be understood and speaks to us in a particular way is indeed something more than a mere meaning bearer. ${ }^{9}$ This somehow is an implicit response to Hegel's remarks on art as "a thing of the past". One can reads and views Gadamer's attempt in reading out the experience of art and his special attention to it from this point of view. His criticism of aesthetic abstraction and his attention to the presentation mode and the living presence of the works of art on the one hand, and, our participation and involvement in encountering them on the other hand, is in line with this issue that it returns art and consequently the artist, departed from the domain of society and the context of culture and its relations and builds an ideal world for himself in his own imagination, to the society and culture scene. Paying attention to the concept of play and the element of participation lies in it somehow refers to this approach. He should "speak" to the community. This Gadamer's central subject matter is in his article "The Relevance of the Beautiful" in which he claims it obviously (Gadamer, 1986, pp. 6-7).

What may be raised regarding festival and the play of work of art is the relation between the copy and the original. The question is whether every performance is a mere repetition and the copy of the same thing which has firstly been held and will always remain as copy while the place of the performance is existentially lower than it? However, Gadamer contrary to Plato does not regard the relation between them ontologically rigid and unchangeable, but performing and holding every celebration in each time is not only considered as a mere copy but also as original. This relation between the copy and original is true regarding both the play and the festival. The nature of the festival is in its periodical repetition. However, the question which immediately would be raised is whether this repetitive mode which is held every year or every few years in a specific period, does not cause that it be considered as a simple and spent repetition and copy in relation to its primary and original? According to what we have discussed, Gadamer's answer to this question is basically negative. To him, there is not an unbridgeable gap between the copy and the original when the audience takes the player's place, here the copy or repetition is considered as the original; therefore it enjoys independency. Representation which constructs the very nature of every play and presentation (or even symbol) is not mere representation of the same thing which previously has occurred or has been encountered. Rustam, which is a mythical hero whom Ferdowsi introduces in Shah Nameh, is more than a historical and real hero. Every presentation or performance is itself an "event" just as understanding itself, because it is not a predetermined and methodic issue. It is not an aesthetic pleasure which leads to the judgment of taste which requires universality and necessity (Kant). Although every presentation has its own particular rule, it is not presented based on a predetermined and fixed "structure" or foundation. In fact, every presentation or performance is not something more than "coming-into-existence of the work itself" (Gadamer, 2004, p. 116). It is because of this issue that Gadamer speaks of "play as structure and structure as play" simultaneously. Accordingly, every presentation is a local and occasional issue, this means that every presentation or play of a work of art occurs in specific times.

\section{Participating as an alternative to "aesthetic differentiation"}

As mentioned, participation is a comprehensive (both theoretical and practical) presence not a thematic look and contemplation. Instead of standing in a particular spot and looking at a subject, we should have an active presence in the midstream. Although we know that any time we enter this midstream, there would be a new water flow. From this perspective, to Gadamer, theoria (watching) is identical to the genuine mode of participation based on its Greek etymon and contrary to the modern scholars' considerations regarding this term:

"Thus watching something is a genuine mode of participating. Here we can recall the concept of sacral communion that lies behind the original Greek concept of theoria. Theoros means someone who takes part in a delegation to a festival. Such the theoros is a spectator in the proper sense of the word, since he participates in the solemn act through

\footnotetext{
9. A work of art is openness and emergence of truth in its Heideggerean sense. This kind of consideration of the artistic truth in its Heideggerian sense (aletheia) is in contrast to the scientific concept of truth (Gadamer, 2004, p. xxii). The mode of this openness in art occurs in a particular mode and in a unique language. It is this issue that differentiates the works of art from other issues that only carries meaning.
} 
his presence at it and thus sacred law accords him a distinction: for example, inviolability." (Gadamer, 2004, p. 122). ${ }^{10}$ It is based to this issue that Aristotle's definition of tragedy and its role in "catharsis" of audiences looking and contemplating it is important for Gadamer. Play is always a communicative activity. Watching a sports competition, like football match, requires entering the world of play and accepting its rules. By entering the world of this play, one may sympathizes more with one of two teams. In this situation, one rejoices when his favorite team gains score or upsets when it loses score. Although one are not one of the players in the stadium, his very participation and companion with them lead to his presence in the world of play. Therefore, Gadamer believes that:

"Another important aspect of play as a communicative activity, so it seems to me, is that it does not really acknowledge the distance separating the one who plays and the one who watches play. The spectator is manifestly more than just an observer who sees what is happening in front of him, but rather one who is a part of it insofar as he literally "takes part"'" (Gadamer, 1986, p. 24).

However, it should be considered that participation is an equivocal issue as the central component of play and the festival. In other words, two interpretations are possible from this issue: first, participation means that one participates, cooperates and sympathizes with others as a collective experience in e.g. a festival, celebration, religious rite. It is on this basis that playing always necessitates "playing along with". This interpretation of participation is true about festivals, carnivals, religious rites and even performing arts. Second, participation means not only collective presence and common experience within a celebration as a whole but also involvement in and acceptance of the rules of play (the play of a work of art) which is there. In fact, it means that the focus is more on the relation of me and play than the collective and universal aspect of participation. This issue is truer regarding literary and visual arts, the arts which one usually encounters with them; however, they may be presented in public places.

If one accepts that "perception always includes meaning" (Gadamer, 2004, p. 80), participating in play of a work of art and the experience of art mean taking part in the emergence of meaning. In other words, participating in the emergence of meaning is a truth that occurs in the domain of art, which itself requires "historical mediation". Therefore, while to Nietzsche, art is a refuge fleeing from truth (Nietzsche, 1998, p. 629), to Heidegger and Gadamer; it is a resort and conduit for the emergence of truth. Participating in play of a work of art is a response to the call of a truth which addresses us. Thus, participation is not Kantian "disinterestedness" -it does not mean suspending all foreign relations and issues which Kant refers to them as "interest" (Kant, 1998, p. 100)- rather it refers to paying attention to the same relations and interestes which one cannot ignore them freely and consciously. ${ }^{11} \mathrm{It}$ is because of the fact that no mere perception occurs without any relation with "content" (for example, the world in which the work is located) and it merely refers to its "form", but according to Hegelian legacy of Gadamer's thought, every form is always consistent to content and is not departed from it.Therefore, he defends "aesthetic non-differentiation". One never hears pure voice, but he always hears a baby's cry or a piece of music echoed in a hall (Weinsheimer, 1985, p. 93). Consequently, relying on the concept of play with the centrality of the concept of participation is to illustrate this point that the issue is something more than mere "aesthetic pleasure" which refers to form of the beautiful. Encountering a work of art and participating in its play in fact is entering the world of the work of art which encounters one with him and causes "self-understanding"(Gadamer, 1976, pp. 100-104; Gadamer, 2004, p. 113). ${ }^{12}$ This "self-understanding" -which is the result of encountering the work of art and participating in its play- is the active aspect and the positive result of participating. Therefore, "aesthetic" becomes part and parcel of hermeneutics and is discussed under hermeneutics because

"At any rate, 'it [the work of art] speaks' ... it says something to each person as if it were said especially to him, as something present and contemporaneous. Thus our task is to understand the meaning of what it says and to make it clear to ourselves and others. Even the nonlinguistic work of art, therefore, falls within the province of the proper task of hermeneutics... It is not only the 'This art thou!' disclosed in a joyous and frightening shock; it also says to us; 'Thou must alter thy life'! (Gadamer, 1976, pp. 100-1)

Thus, contrary to Kantian aesthetics, the possibility of issuing universal and necessary judgements by judging subjects and its presupposition for other judgeing subjects is ruled out. It is obvious that Gadamer's mode of interaction

10. Gadamer, in the article "The Artwork in Word and Picture", again refers to the primary and original meaning of the term theoria in Greek. He discusses this issue that for the Greek, the term theoria did not mean mere observation and an unbiased observer but means "to be fully there" (Gadamer, 1993, p. 213).

11 . However, Heidegger, contrary to Schopenhauer and consequently Nietzsche, has another interpretation of Kantian "interestedness" by his phenomenological method (Heidegger, 2009, pp. 157-8).

12. The peculiar nature of our experience of art lies in the impact by which it overwhelms us (Gadamer, 1986, p. 34). 
with art and the experience of art are influenced by basic components of his philosophical hermeneutics and have a total link to it.

\section{Conclusion}

What has attracted Gadamer to modern aesthetics' criticism is a subjectivism in whose foundation he observed. Using concepts such as play, symbol, festival ..., he is to discuss the experience of art in another method. He, by resorting to these concepts and generalizing them to the constellation of art and the way of one's encountering works of art, is to transcend from this "subjectivization" of aesthetics by Kant. By focusing on the concept of participation as the central and common component between the notion of play and festival, Gadamer in fact adopts a hermeneutical approach to art and the experience of art; which is a view that knows a work of art as a going on and temporal play or festival which one embarks on and keeps its meaning alive for oneself rather than considers it as a mere object of aesthetic consciousness lacking in time and a context. As mentioned, the concept of participation has two implicit meanings within itself which has different implications regarding the concept of play of a work of art on one hand and the concept of festival as a collective religious ceremony.

\section{Bibliography}

Ford, Martin (2006). Gadamer's Transformation of Hermeneutics: from Dithey to Heidegger. M. A. Thesis in philosophy, Brock University.

Gadamer, Hans-Georg (1964). Aesthetics and Hermeneutics. In Philosophical hermeneutics (pp. 95-104), trans. \& ed. By David E. Ling, California, University of California Press.

Gadamer, Hans-Georg (1973). The play of art. In The Relevance of the Beautiful and Other Essays (pp. 123-130), trans. By Nicholas Walker, ed. \& with an introduction By Robert Bernasconi, Cambridge, Cambridge University Press.

Gadamer, Hans-Georg (1986). The Relevance of the Beautiful: Art as Play, Symbol and Festival. In The Relevance of the Beautiful and Other Essays (pp. 3-53), Trans. By Nicholas Walker, ed. \& with an introduction By Robert Bernasconi, Cambridge, Cambridge University Press.

Gadamer, Hans-Georg (1993). The Artwork in Word and Image: 'So True, So Full of Being!'. In The Gadamer reader: a bouquet of the later writings (PP. 195-224), trans. \& ed. by Richard E. Palmer, Evanston, Northwestern University Press.

Gadamer, Hans-Georg (2004). Truth and Method. Trans. \& translation revised by Joel Weinsheimer and D. G. Marshall,. London and New York: Continuum.

Graham, Gordon (2004). Philosophy of Arts: An Introduction to Aesthetics. Trans. (into Persion) by Masoud Olia. Tehran: Ghoghnus Press.

Heidegger, Martin (2009). Nietzsche, V. 1, Trans. (into Persion) By Iraj Ghanuni. Tehran: Agah Press.

Hoy, David C. (2006). The Critical Circle: Literature, History and Philosophical Hermeneutics. Trans. (into Persion) by Morad Farhadpour. Tehran: Roshangaran Press.

Kant, Immanuel (1998). Critique of Judgement. Trans. (into Persion) by abdolkarim Rashidian. Tehran: Nai Press.

Karnezis, G. T., (1987), Gadamer, Art, and Play. [Online available]: http://www. Svcc.edu/ academics/cases/murry IGadamer/gadartpl.htm.

Kelly, Michael (2004). A critique of Gadamer's Aesthetics. In Gadamer's Repercussions (Reconsidering Philosophica Hermeneutics) (PP. 103-120). Ed. by Bruce Krqjewski. California: University of California Press.

Khatami, Mahmoud (2008),. Discourse on Phenomenology of Art. Tehran: Farhangestan-e- honar (Academy of art).

Nietzsche, Friedrich (1998). The Will to Power. Trans. (into Persion) by Majid Sharif. Tehran: Jami Press.

Nordenstam, Tore (1984). The essence of Art- Wittgenstein Vs. Gadamer. In Aesthetics (pp. 23-28), ed. by Rudolf H., Vienna, Holder.P. $\mathrm{T}$.

Scheibler, Ingrid (2001). Art as Festival in Heidegger and Gadamer. In International Journal of Philosophical Studies (pp. 151-175). Vol. 9 (2).

Vikhagen, Arne. K. (2009), Gadamer's concept of play. [Online available]: http://sensuosknowledge.org/wpcontent/uploads /2009/04skl_ak_Vikhagen_spiel.pdf.

Weinsheimer, Joel (1985). Gadamer's Hermeneutics: A reading of Truth and Method. New Haven and London: Yal University Press.

Weinsheimer, Joel, (2002), Philosophical Hermeneutics and Literary Theory. Trans. (into Persion) by masoud Olia. Tehran: Ghoghnus Press. 